\title{
11
}

\section{Medicare: The making and consolidation of an Australian institution}

\author{
Anne-marie Boxall
}

\section{A popular and entrenched institution}

Medicare, the foundation of Australia's universal healthcare system, has been in place for nearly 35 years. It has hardly changed during that time. Medicare's main objective was to ensure all citizens had access to affordable basic health care. Its core features came on line fairly quickly. Universal entitlement to subsidies for medical services came into effect from 1 February 1984 after the Hawke Government passed legislation to establish a medical benefits scheme. Free treatment in public hospitals was also guaranteed because the Commonwealth had already successfully negotiated funding agreements with the states and territories.

While public support for Medicare was fragile in the leadup to its introduction, its popularity has grown over time. Medicare is now widely considered to be one of the country's greatest policy achievements-or, in the words of a 2014 opinion piece: '[I]f a popularity contest was staged for Australian government programs Medicare would walk into the final' (Wade 2014). 
Data to substantiate this claim came from a 2011 Essential Poll, in which respondents were asked their views on some of the most significant Commonwealth Government policy decisions over several decades. Medicare received overwhelming support, with almost 80 per cent of people saying it was good or very good. Approval of Medicare rated far higher than either the floating of the Australian dollar or free-trade agreements (Wade 2014). In the most recent iteration of this poll, published in 2016, the proportion of people who agreed that Medicare was good for the country had fallen to 56 per cent, but it was still ranked as the second most popular government initiative (compulsory superannuation was ranked first) (Essential Research 2016).

Medicare's popularity does have a downside. The public is now so fond of Medicare that it is difficult for governments to make any changes to it at all. The Coalition Government discovered this when it proposed a $\$ 7$ co-payment for a visit to a general practitioner (GP) in the 2014-15 Budget (Department of the Treasury 2014). The government said the change was needed to ensure the growing costs of health services were sustainable and argued that the move demonstrated its commitment to Medicare long into the future (Department of the Treasury 2014). The public did not buy it and the controversial proposal was eventually dropped.

In 2016, the Coalition was reminded how much the public loved Medicare when it suggested that the back-end payment systems might need modernising (Glance 2016a). The government proposed a taskforce to investigate the options, but one of them was to have private companies run the Medicare payment system (Glance 2016b). The Labor opposition seized on the idea, characterising it as the 'privatisation of the Medicare system', 'the thin end of the wedge' and the beginning of the Coalition's attempt to savage 'bulk billing and eliminate universal healthcare in this country' (Shorten 2016).

Despite widespread criticism of Labor's tactics, the 'Mediscare' campaign, as it became known, was effective. It gave Labor a significant boost in the polls and forced the Coalition to spend the rest of the campaign publicly defending its commitment to Medicare (Muller 2017). The Coalition eventually won the election, but by only one seat (AEC 2016). It now seems that even the most peripheral, behind-the-scenes changes to Medicare carry substantial political risks for governments. 


\section{Context: Medicare's tumultuous trajectory}

Because support for Medicare is now so strong, it is hard to imagine it was ever a contentious policy, but it was. The ALP first proposed a universal health insurance scheme in July 1968. In the following years, public opinion on the relative merits of universal health insurance and private health insurance fluctuated widely (Grant 2000: 261). When the Whitlam Labor Government eventually implemented universal health care in 1975-in a scheme called Medibank-public support for it was fragile. The majority of people polled said they preferred Medibank over private insurance, but a large proportion of people were undecided (Grant 2000: 261).

The medical profession was far from undecided. Large sections of the medical community vehemently opposed Medibank. The peak medical body, the Australian Medical Association (AMA), mounted a massive campaign designed to stop the introduction of Medibank. It led to a legislative stalemate that was resolved only after a double-dissolution election and the first (and only) joint sitting of parliament, in 1974. After Medibank eventually became law, it was another year before the Whitlam Government could convince all the states and territories to sign up to Medibank (their cooperation was needed to implement the hospital side of Medibank). Medibank was finally up and running across the country by October 1975. Just weeks later, the Whitlam Government was dismissed (Boxall and Gillespie 2013).

When the Fraser-led Coalition Government was elected in December 1975, it promised to maintain Medibank, despite years of opposing the scheme in public and in parliament. Fraser (1976) explained away his policy backflip by stating:

Look, time marches on. Circumstances change and you deal with circumstances as they are. Medibank was introduced. Amongst many people it was plainly popular. It would have been destructive and unreasonable to attempt to break Medibank.

Fraser did not keep his promise once in government. Within six months of coming to power, the government began modifying Medibank. After a series of major changes designed to find a way of balancing Medibank with private health insurance, in 1981, the Fraser Government decided to 
abolish Medibank. Australia was left with a system of voluntary private insurance and the shame of being the only advanced economy to have dismantled a universal healthcare system (Boxall and Gillespie 2013).

Fortunately, Australia's health reform journey did not end there. When the Hawke Labor Government came to power in 1983, it began making plans to implement Medicare-a virtual carbon-copy of Medibank.

Public support for universal health care waxed and waned during the Fraser years, but polls taken in 1983 and 1984 showed the majority of people were in favour of Medicare. As time went on, the number of people undecided about the merits of Medicare fell and support for it continued to grow (Grant 2000: 264). Some powerful segments of the medical profession (medical specialists in particular) were still strongly opposed to Medicare, but they were in the minority. The Coalition, however, was still dead against it. In 1983, when Labor was preparing to implement Medicare, opposition health spokesman Jim Carlton threatened to abandon it as soon as the Coalition was reelected (Blewett 1983: 410). The Coalition was still threatening to dismantle Medicare almost a decade after it was fully implemented. In opposition in 1987, John Howard reportedly said Medicare had 'raped the poor of this country' and he would stab Medicare in the stomach if the Liberals regained office (O'Connor 2003; Elliott 2006).

The Coalition did not fully accept Medicare until 1995. Like Fraser before him, Howard (1995) explained that his party had changed its mind on Medicare because Australians wanted to keep it. It had become clear to the Coalition that there would be serious electoral consequences for opposing Medicare. Data from the Australian Electoral Study over time highlight the point. In five of the six election surveys conducted after 1990, respondents ranked Labor higher than the Coalition on health issues. According to analyst Richard Grant, this can be explained in part by perceptions that Labor would spend more on health, but the results also reflected the public's strong preference for retaining Medicare. Grant argues that the margin between the parties was greatest in 1993 when voters were still uncertain about the Coalition's commitment to Medicare (Boxall and Gillespie 2013: 156-7).

Since 1995, both sides of politics have been competing to demonstrate their commitment to Medicare, with both claiming to be its principal advocate and protector (Boxall and Gillespie 2013). 


\section{Agenda-setting: Getting Medicare (back up)}

The Hawke Labor Government was elected on 6 March 1983 when Australia was in the midst of the worst economic recession for 50 years. Inflation was high, at about 11 per cent, and unemployment had skyrocketed from 5.5 to 9.9 per cent between March 1982 and March 1983 (ABS n.d., 1983). Despite this, the Hawke Government managed to implement Medicare on 1 February 1984, less than a year after coming to power. This was possible only because Medicare had been an integral part of Hawke's key election pitch to introduce the Prices and Incomes Accord.

The accord was an agreement on economic reform, negotiated in 1982 between the ALP, while in opposition, and the powerful Australian Council of Trade Unions (ACTU). The accord's main aim was reviving the economy, creating new jobs and establishing the conditions for strong economic growth into the future. To succeed, however, the accord had to find a way of preventing an explosion in wage growth once the economy began to recover. Labor's plan was to get the unions to cooperate and agree to accept a return to centralised wage fixing and refrain from making any additional wage claims (except in extraordinary circumstances) (Kelly 1992: 61-2).

As a former ACTU leader, Hawke knew the unions would demand something in return for their cooperation on wage restraint-for example, better social welfare. He also knew the impact social welfare reforms would have on the Budget; Medibank, Whitlam's universal health insurance scheme, cost $\$ 1.6$ billion in its first year of operation (1975-76) (Biggs 2004). The brilliance of Hawke's accord was that it managed to find a way of offsetting the costs of social welfare reforms without losing union support for its key elements.

Hawke promoted the concept of the 'social wage' as a means of securing union support for the accord, explaining that it would deliver benefits in lieu of wage rises until the economy began to recover (Kelty and Howe 2003). The social wage included Medicare and other promised improvements in areas such as industry and education and training for the unemployed. 
Medicare was the most important element of the social wage. Neal Blewett, Hawke's first health minister, explained that because the concept of the social wage was vague, the unions wanted to be able to say to their members: 'We're asking for wage restraint, but we are giving you Medicare.' ${ }^{1}$ Bill Kelty, then secretary of the ACTU, agreed with Blewett that Medicare was a critical element of the accord. ${ }^{2}$ He explained that Medicare was a strategically important issue for the ACTU because all unions supported it.

Restoring universal health care had become important to the unions during the turbulent Fraser years. While in power, between 1976 and 1983, the Fraser Government made a series of major changes to Australia's health insurance system. The first came in 1978, when the government made health insurance optional, effectively ending universal health care. In 1981, the government abandoned the public insurance scheme (Medibank), which pushed people into private insurance or no insurance at all (Boxall and Gillespie 2013). After the Fraser Government abolished Medibank, the unions became the chief advocates for restoring universal health care. They could see that their members - many of whom were low and middle-income earners - had the most to gain from making health care more affordable (Blewett 1983: 410; Boxall and Gillespie 2013).

Blewett (1983) made the integral links between Medicare and economic recovery plain when he introduced the Medicare legislation into parliament in 1983. He explained that the Bills (the Health Legislation Amendment Bill 1983 and related levy Bills)

are an essential part of the Government's economic strategy. Not only do they embody a health insurance system that is simple, fair and affordable, but they represent an advance in the social wage and our accord with the trade union movement, and in moderating the impact of inflation. Medicare will play its part in economic recovery. (Blewett 1983: 410)

He went on to highlight that Medicare was estimated to reduce the consumer price index by 2.6 per cent in the first half of 1984, making it a key part of the government's anti-inflation strategy (Blewett 1983: 410).

1 Neil Blewett, Interview with the author, Blackheath, NSW, 4 December 2006.

2 Bill Kelty, Interview with the author, Melbourne, 15 March 2007. 


\section{Design and choice: Medicare's value proposition}

The Hawke Government's central promise during the 1983 election campaign was to fight inflation and unemployment simultaneously (Kelly 1992: 60). However, the problems the government faced in health policy also required urgent attention.

Access to affordable health care had become a major problem in Australia, particularly after Medibank was abolished in 1981. In 1982, a survey by the Australian Bureau of Statistics (ABS 1984) found that 2 million Australians were without health insurance cover (from a total population of approximately 15 million). Just a few years earlier, all Australians had been covered under Medibank.

One of the main benefits of the Medicare scheme was that it was simple, particularly compared with the complex private insurance arrangements that existed under the Fraser Government. Under Medicare, there would be one national insurer and all Australians would be automatically covered for basic hospital and medical services. Medicare would entitle people to treatment in a public hospital, as an inpatient or outpatient, without charge. It would also cover part or all of the cost of treatments provided by GPs, medical specialists and surgeons and diagnostic services (such as radiology and pathology). Benefits for a limited range of nonmedical services, including optometry and selected dental surgical procedures, would also be available (Blewett 1983: 401).

After 1978, when health insurance became optional, people had to decide whether or not to purchase health insurance. This meant making an assessment of the risk of ill health (yours and your family's), and then deciding whether to purchase private health insurance or to self-insure (by paying the cost of any health expenses out of your own pocket). Various factors had to be considered when making this decision because government benefits for medical services varied according to income level and insurance status and some benefits were payable only after a substantial copayment was made (Boxall and Gillespie 2013: 79).

In stark contrast with the complicated arrangements under the private insurance scheme, Medicare would pay a single medical benefit rate for all patients. In his second reading speech on the Medicare Bills, Blewett (1983: 400) explained that, under the current arrangements, 
the Commonwealth Government paid 85 per cent of the scheduled medical fee for pensioners, 30 per cent for people with private insurance and nothing for people without health insurance. He went on to outline the problems that arose because there were different income limits for different entitlement cards. These arrangements meant that pensioners could earn more than a low-income earner but still retain their health concession card. He then illustrated the complicated decision-making process required of individuals:

[A]n itinerate labourer on varying weekly incomes is asked to average his income from the last four weeks, check to see if it is less than $\$ 193$ a week for a married couple, and notify the Department of Social Security if his income exceeds that average by more than 25 per cent in any one week.

(Blewett 1983: 400)

As well as being simpler, Medicare was also promoted as being far more efficient than the private health insurance scheme. Eligibility checks would not be required under Medicare and doctors and hospitals would no longer have to chase bad debts, which would reduce the administrative burden on them (Blewett 1983). One of the key features of Medicare was that it allowed doctors to direct bill, or 'bulk-bill' as it is now known. If they opted to bulk-bill, doctors would be paid directly by the government on the condition that they accept the Medicare benefit rate as full settlement of the account for that service.

The government also estimated that it would cost about $\$ 40$ million a year less to administer medical benefits through a single national insurer than it would through existing private insurers (there were about 80 in operation at the time). Blewett (1983: 408) explained that the Health Insurance Commission (which administered the government-run private health insurance fund, Medibank Private) would be administering Medicare and it had lower overheads than comparable private insurers.

One of the strongest public arguments the government made for Medicare, however, was that it was more equitable than the existing private health insurance scheme. Blewett explained that the cost of health care had become a strain for many people. If they chose to self-insure and then became ill, people who were ineligible for government support faced high medical and/or hospital expenses. The alternative-taking out private health insurance-was also becoming increasingly unaffordable for many low and middle-income earners. As premiums rose, it was far more difficult for those on low and middle incomes to afford insurance. 
In contrast with private insurance, Medicare would be financed through a levy on taxable income. This meant all Australians would 'contribute towards the nation's health costs according to his or her ability to pay', but people would have the same entitlements to care regardless of their income (Blewett 1983: 400).

Medicare was undoubtedly simpler and more equitable and efficient than the private health insurance scheme; however, there were alternative policy proposals canvassed at the time that also had merit. The two main options were: expanding the Community Health Program or establishing health maintenance organisations.

The Community Health Program was implemented by the Whitlam Government in 1973. It established community health centres across Australia and aimed to support alternative methods of delivering health care (De Voe 2003). These centres had a strong focus on preventive health and early intervention, providing support and education to reduce the risk of disease and the consequences of it and to deliver care to the local community (Sax 1984: 104-6). The proposal to expand community health centres was controversial because many centres required medical practitioners to become salaried employees.

Health maintenance organisations (HMOs) were also considered as an alternative to Medicare. This policy idea was first floated in 1973 as an alternative to Medibank and was revived in 1979 by Labor's shadow minister for health Richard Klugman. It was rejected once again, largely because it meant moving away from the longstanding fee-for-service funding model for doctors (Scotton and Macdonald 1993). The main reason Medicare was chosen over these alternatives was because it would be relatively quick to implement. Because Medibank had operated between 1974 and 1981, the government already had the infrastructure it needed to process health insurance claims across the country.

The cash-strapped states and territories signed up to the Medicare hospital agreements within weeks of the Commonwealth's offer. Once Medicare began, free access to public hospitals was restored. The government also did not have to do much to explain Medicare to the public. Because Medicare was identical to the original Medibank scheme (which operated until 1978), the public and healthcare providers already knew how Medicare would work and what it would mean for them. 
The case for implementing Medicare was also clear. Blewett (1983: 411) pointed out that Labor had outlined its plans for Medicare, including detailed costings, more than a year before the 1983 election. It had also produced a booklet entitled Labor's Health Plan: Summary of arguments and circulated it widely among journalists and the public. In his second reading speech, Blewett (1983: 399) also acknowledged that the 'principles of the Medicare plan [were] similar to those of Medibank as it was originally introduced in 1975 '. Although associating itself with the Whitlam Government carried some political risk for Labor, in the case of Medicare, it was worth it because Whitlam had begun advocating for an equitable, efficient and simple health insurance scheme in 1968 (Boxall and Gillespie 2013).

\section{Implementation: Making Medicare a reality}

On the first anniversary of Labor's election, on 5 March 1984, Bob Hawke gave a speech to the Health and Research Employees' Association celebrating the government's achievements in transforming Medicare from 'nothing more than a policy document' into a 'simple, equitable, efficient and universal health scheme' (Hawke 1984). The celebration, while justified eventually, was premature.

Hawke's rhetoric was an attempt to hose down a major dispute with the medical profession that had erupted over Medicare. The key point of contention was doctors' rights to practice privately in public hospitals. The bulk of Hawke's speech was dedicated to defending the government's position on the issue and outlining the compromises it had already made in an attempt to resolve the dispute. Despite Hawke's efforts, the dispute intensified and dragged on for another year.

The dispute with the medical profession began even before the details of Medicare's implementation were finalised. Early in his tenure as health minister, Blewett was putting pressure on the medical profession to accept lower increases in the scheduled fee for medical services as part of the government's pursuit of wage restraint (Legge and Metherell 1984). When the government subsequently proposed changes to employment contracts for doctors working in public hospitals as part of Medicare, relations with the medical profession-and medical specialists in particulardeteriorated further. 
The problem, according to medical specialists, was that the proposed changes to the Commonwealth's Health Insurance Act would give the Minister for Health a role in determining employment contracts for doctors in public hospitals (previously a state matter) and put limits on medical specialists' salaries and fees. The dispute had national implications even though it was most intense in New South Wales (doctors there had different contract arrangements with public hospitals than their colleagues in other states) (AMA 2012).

In January 1984, just a month before Medicare was due to start, the government tried to deescalate the dispute by announcing an inquiry into medical specialists' rights to private practice in public hospitals. The move led to a fragile truce between the government and the peak medical group, the AMA, but it did not last long (Haley 1984). A month after Medicare began, in March 1983, medical specialists were threatening week-long rolling strikes and the AMA was still demanding the Commonwealth withdraw its legislative changes on hospital contracts (Milliner 1984a, 1984b).

The government soon made a series of concessions that made the hospital contracts more acceptable to medical specialists in all states except New South Wales (the main concessions made were agreeing to formal consultations with the profession on the proposed legislative changes and appropriate arbitration and appeal procedures in the event of ongoing disagreement) (Cook 1984). In New South Wales, industrial action continued, and specialists began resigning their posts in numbers large enough to frighten the state and Commonwealth health ministers. In May 1984, more than 100 orthopaedic surgeons had resigned from public hospitals in New South Wales. Other specialists soon followed, and the number of resignations grew to more than 1,000. The number of surgeries in public hospitals was cut by half and waiting times for some elective procedures grew by 18 months (AMA 2012).

In April 1985, more than a year after Medicare began, the government made further concessions and withdrew its proposed amendments to the relevant section of the Health Insurance Act (Section 17). The following month, medical specialists returned to work in public hospitals and the Commonwealth's legislation was passed (Adams 1986; AMA 2012). The dispute was the most significant implementation challenge the government faced over Medicare. 
While the dispute did have a major impact at the time, particularly on access to public hospital care for patients in New South Wales, the Hawke Government had a much easier time introducing Medicare than the Whitlam Government had with Medibank. While the AMA fought vigorously to change the legislation concerning doctors' hospital contracts, it did not object to Medicare on principle. In contrast, the AMA strongly opposed Medibank and invested enormous organisational and financial resources into stopping it being introduced. After several years of sustained, vigorous campaigning against it, the AMA eventually lost the battle over Medibank and the organisation was substantially diminished as a result. Its loss over Medibank affected its ability and willingness to oppose the introduction of Medicare.

Several leading medical advocates have attributed the AMA's declining influence over government policy decisions to the battle over Medibank. One of the main reasons was a proliferation of medical interest groups during that period, which meant the profession was fragmented and unable to promote a unified position (Boxall 2008: 198-200). One former AMA president admitted that, by the time Medicare came along, Blewett was able to 'divide and conquer'. ${ }^{3}$ Even at the time, Blewett acknowledged the political battle over Medicare was far more rational and reasoned than the debate over Medibank had been. In his second reading speech, Blewett (1983: 399) said:

I am pleased to say that while there has still been considerable opposition to our health insurance proposals, on this occasion the debate has been more reasoned and rational in its tone. Our opponents for the most part restricted themselves to differences of opinion, rather than the litany of distortions and alarums of 1973 and 1974.

Many years later, Blewett confirmed this, recalling that negotiations with the AMA over Medicare were quite reasonable. He explained that the AMA leadership wanted to find a compromise because it did not want another stand-up fight like the one it had with Bill Hayden over Medibank. ${ }^{4}$

3 L. Thompson, Interview with the author, Sydney, 21 November 2006.

4 Blewett, Interview with the author. 


\section{Medicare's endurance (and limitations)}

Using policy endurance as a measure, Medicare is a remarkable success. It continues to guarantee all citizens access to public hospitals without charge and provides benefits for a wide range of medical services inside and outside hospitals. Its scope has expanded a little over the period, with benefits for allied health services and dental services for children now available, but only in limited circumstances.

Measured against its original programmatic objectives-simplicity, efficiency and equity-Medicare still performs relatively well. It is still funded through taxation, ensuring that access to care is determined by clinical need rather than ability to pay. Rules on eligibility and entitlement to benefits are still simple, clear and consistently applied.

Australia also achieves good health outcomes relatively efficiently, according to a recent OECD report on the performance of Australia's health system (OECD 2015). Government expenditure on health as a proportion of total expenditure remains relatively stable. Between 2005-06 and 2015-16, government health expenditure hovered between 66.9 per cent (2014-15) and 69.9 per cent (2011-12) (AIHW 2017). While total health expenditure has outpaced economic growth over the past 25 years, it has not grown any faster than government revenue or the wealth of individuals (AIHW 2016a).

In recent years, bulk-billing rates have become the litmus tests of a government's commitment to Medicare and its inherent fairness (Boxall and Gillespie 2013: 176). Bulk-billing preserves equity in the health system because patients do not incur any charges for the services provided. Politicians from both sides proudly claim the highest bulk-billing rates on record whenever they are in government (Norman and Gillespie 2013; Hunt 2018). However, as a measure of success, bulk-billing rates are a curious choice. Politicians generally only highlight bulk-billing rates for GP services, which are high compared with other types of care. National data from the December 2017 quarter show that 84 per cent of GP visits were bulk-billed. For the same quarter a decade earlier, in 2007, the bulkbilling rate was 78 per cent (Department of Health 2017).

In contrast, bulk-billing rates for some other services are very low and vary considerably across geographic regions. Nationally, only 31 per cent of medical specialist services were bulk-billed in the December 2017 quarter. 
In Western Australia, only 20 per cent of specialist services were bulkbilled in the December 2017 quarter, compared with 38 per cent in the Northern Territory. Only 28 per cent of allied health services funded under Medicare were bulk-billed in the Australian Capital Territory during that same period, while in South Australia the figure was 75 per cent.

What these low bulk-billing rates in some areas reveal is that Medicare's ability to deliver on its promise of equitable, affordable access to care depends in part on the type of care you need and where you live. While this was true to some extent at the time of Medicare's inception, the problem has become more significant over time as people's health needs have changed.

When Medicare was designed in the 1960s, the main causes of ill health or premature death were childbirth, poor nutrition and communicable diseases, such as influenza and tuberculosis. Today, chronic diseases such as diabetes, cancer and heart disease are the main causes of ill health and premature death (Lozano et al. 2012). The growing burden of chronic and complex diseases means that people need health care over long periods, from many different types of health professionals, not just medical doctors. As technology has advanced, much of the care people need can now be provided in the community instead of hospitals. And in some areas-surgery, rehabilitation and mental health, for example-most activity occurs in private, not public, hospitals (AIHW 2016b).

The gradual shift in service delivery away from medical and public hospital-based care is revealing Medicare's limitations as a means of ensuring affordable access to care. This has significant implications for Medicare and its legitimacy and endurance, now and into the future. For many people with chronic and complex conditions, nursing, dental and allied health services (for example, from physiotherapists and dieticians) are essential. Often, they are provided outside public hospitals and attract limited or no Medicare benefits. As a result, many patients have to pay for these services out of their own pockets.

The ABS survey on patients' experiences of health care found that some people were reporting they delayed access to care because of the high cost. In the 2016-17 survey, for example, nearly one in five people (18 per cent) who needed to see a dental professional said they delayed treatment or did not seek it due to cost. The figures were higher among people living in areas of most socioeconomic disadvantage (26 per cent) compared with 
those living in areas of least disadvantage (11 per cent) (ABS 2017). There is also evidence that some people are finding it difficult to access services even when they are covered by Medicare. Data from the 2016-17 ABS survey on patient experiences show that one in 14 people ( 7 per cent) surveyed who needed to see a medical specialist said they delayed or did not seek treatment due to cost (ABS 2017).

Almost half of all Australians purchase private health insurance, which provides coverage and benefits over and above Medicare. There is also evidence, however, that affordable access to care is even a problem for some people who have purchased private health insurance. The extent of the problem was outlined in a 2017 Senate committee inquiry into the value and affordability of private health insurance and out-of-pocket medical costs (Senate Community Affairs References Committee 2017). The committee's report noted that the number of private insurance policies that excluded cover for certain types of care had dramatically increased in recent years. It highlighted numerous cases where people faced large, unexpected healthcare costs. In one case, a consumer complained that they had held top-level cover with a major private insurer for over 15 years, but when they needed to make a claim on it (for their daughter's braces and an operation), they found they were not covered and had to pay $\$ 16,000$ out of pocket (Senate Community Affairs References Committee 2017: 8).

The committee's report also highlighted the impact of high out-of-pocket costs on access to care for people with chronic conditions. A submission from Allied Health Professions Australia, for example, argued that high out-of-pocket costs for people with chronic diseases were making health services less accessible and people were 'avoiding treatment and increasing their risk of avoidable health issues' (Senate Community Affairs References Committee 2017: 17). In another submission, Parkinson's Australia explained that it was aware that some of its members had mortgaged their houses or dipped into their superannuation to pay for treatment that was considered to be appropriate and cost-effective (Senate Community Affairs References Committee 2017: 18).

The equitable nature of Medicare is one of its core objectives and achievements, but it is being undermined as the cost becomes a barrier to accessing essential health care. While public and political support for Medicare remains strong, it is difficult to imagine that this will continue if problems with affordable access to care persist. 
As discussed earlier, alternatives to Medibank and Medicare were considered at crucial decision points. In the late 1960s, the Whitlamled Labor opposition gave cursory consideration to expanding the Community Health Program as the means of delivering on its promise to ensure universal health care. In the late 1970s, when Medibank was being dismantled, Labor considered introducing HMOs (Boxall and Gillespie 2013). Both policy alternatives had some advantages over Medicare in terms of ensuring affordable access to health care, particularly for chronic conditions.

The vision for an expanded Community Health Program was for salaried doctors working in the community to coordinate a range of health services, including preventive health care (Sax 1984: 102). The costs of care could be controlled if doctors were paid a salary instead of a fee for each service delivered. A key advantage of the HMO model was that the organisation would take responsibility for delivering all healthcare services to members, inside and outside hospitals. Members would pay a fixed fee, which would limit the risk of unexpectedly high out-of-pocket costs (Sax 1984: 202).

Neither option was taken up at the time, but the existence of viable alternatives does raise the question of whether or not it might be time to consider an alternative to Medicare-one that is better able to address the health policy challenges of the twenty-first century.

Some analysts argue strongly that Medicare is so structurally flawed that fundamental reforms to the health system are needed. Jeremy Sammut (2016: 4) from the Centre for Independent Studies, for example, explains:

Medicare does not in all cases provide access to the full range of medical, pharmaceutical and allied healthcare that might ensure chronic conditions are properly managed to stop patients ending up in hospital

He criticises government inertia on major health system reform, arguing that

the political reality is that neither level of government has been willing to address the real chronic condition in the Australian health system: the structural problems that mean that Medicare is not a 'health system' per se, but primarily functions as a series of provider-oriented payment mechanisms for separate sets of non-hospital and hospital-based services. 
Medicare does not operate as a comprehensive health insurance system that offers patients all necessary and beneficial care, no matter the setting or provider. (Sammut 2016: 5)

Other analysts agree that Medicare has flaws but suggest a less radical approach to reforming the health system. Stephen Duckett, former secretary of the Commonwealth Department of Health and currently Health Program Director at the Grattan Institute, argues that Medicare has been a great success in terms of what it set out to achieve. He goes on to highlight the major problems that need to be addressed through reform:

- removing the financial barriers to care

- reducing waiting times for surgery and emergency department care

- improving the safety, quality and efficiency of care

- making care more seamless

- developing a stronger emphasis on preventing ill health.

However, in contrast with Sammut, Duckett (2014) argues that the next generation of health reformers needs to recognise that our current health system has many strengths and they must find a way to build on them and fill the gaps left by Medicare.

\section{Conclusion}

As this chapter has shown, on all dimensions of policy successprogrammatic, process and political-Medicare is now an outstanding success. However, the most valuable lessons from the Medicare case study come from examining it in the context of time. As far as notions of success go, Medicare's history and its future are the most interesting dimensions.

Because Medicare has endured for so long, it gives policy analysts the opportunity to examine how dimensions of policy success might change over time. This chapter shows that tensions between the political and programmatic dimensions of success can emerge over time, creating challenges for policymakers. Medicare was initially more successful in programmatic and process terms. Over time, Medicare has become a major political success, but weaknesses in the program have begun to emerge. 
Medicare now has iconic status in Australian health policy and politics. It is the high-water mark against which bold new policy proposals are compared, in health and other social policy portfolios. When the landmark National Disability Insurance Scheme was proposed, prime minister Julia Gillard (2010) claimed that it rivalled 'Medicare as a nation-changer'. The degree to which Medicare has become a political success is now undermining the prospects of long overdue reform to elements of the program.

Medicare's history is also a critical dimension of its success. Medicare was introduced in Australia in the mid-1980s - a time when governments around the world were scaling back state welfare expenditure, particularly universal programs such as health care. The Hawke Government made Medicare affordable by introducing it as part of a larger program of economic reform. However, the most critical dimension of the successful introduction of Medicare was that it had been implemented before. It is very unlikely the Hawke Government would have proposed introducing Medicare if Medibank had not preceded it.

Medibank softened the ground for Medicare. The value proposition for Medicare had already been made, the details of how the program would work were well known, the public and providers had experienced it in practice, the infrastructure was in place and most of the medical profession was no longer willing to fight against it. Many years after the event, Neal Blewett, the health minister responsible for implementing Medicare, commented that he was aware the government had little time to waste if it wanted to implement Medicare. He explained: ' $[\mathrm{M}] \mathrm{y}$ theory has always been the later you did this, the tougher the battle would be.' He went on to say:

[B]y international comparisons we did it [implemented Medicare] just in time ... if we had tried to do it in 1984 without, I think, the preliminary of Medibank, it would have been very, very much harder and may not have been possible. Medibank, for all its short-term survival, did a lot to make the task ten years later a much easier. ${ }^{5}$ 
Instead of distancing itself from the Medibank scheme and the negative associations it had with the controversial Whitlam Government, the Hawke Government embraced it. Perhaps Medicare's greatest claim to success is that it looked to the past-in particular, past failures-as a means of securing the opportunity for reform.

\section{References}

Adams, A. I. 1986. 'The 1984-85 Australian doctors' dispute.' Journal of Public Health Policy 7(1): 93-102. doi.org/10.2307/3342127.

Australian Bureau of Statistics (ABS) n.d. The Labour Force Australia: March 1983. Catalogue No. 6202.0. Canberra: ABS.

Australian Bureau of Statistics (ABS) 1983. Consumer Price Index: March quarter 1983. Catalogue No. 6401.0, 28 April. Canberra: ABS. Available from: www.ausstats.abs.gov.au/ausstats/free.nsf/0/C42EBF2ACD5B659ECA 25753C001108C1/\$File/64010_Mar1983.pdf.

Australian Bureau of Statistics (ABS) 1984. 'Health.' In Year Book Australia, 1984, Catalogue No. 1301.0. Canberra: ABS. Available from: www.abs.gov. au/AUSSTATS/abs@.nsf/DetailsPage/1301.01984?OpenDocument.

Australian Bureau of Statistics (ABS) 2017. Patient Experiences in Australia: Summary offindings, 2016-17. Catalogue No. 4839.0, 13 November. Canberra: ABS. Available from: www.abs.gov.au/ausstats/abs@.nsf/mf/4839.0.

Australian Electoral Commission (AEC) 2016. 2016 Federal Election: House of Representatives_Final results. Canberra: AEC. Available from: results.aec.gov. $\mathrm{au} / 20499 /$ Website/HouseDefault-20499.htm.

Australian Institute of Health and Welfare (AIHW) 2016a. 25 Years of Health Expenditure in Australia: 1989-90 to 2013-14. 5 February. Canberra: AIHW.

Australian Institute of Health and Welfare (AIHW) 2016b. Australia's Hospitals 2016-17: At a glance. Health Services Series No. 85, Cat. No. HSE 204, 27 June. Canberra: AIHW. Available from: www.aihw.gov.au/getmedia/d5f4d 211-ace3-48b9-9860-c4489ddf2c35/aihw-hse-204.pdf.aspx?inline=true.

Australian Institute of Health and Welfare (AIHW) 2017. Health Expenditure Australia 2015-16. 6 October. Canberra: AIHW. Available from: www.aihw. gov.au/reports/health-welfare-expenditure/health-expenditure-australia2015-16/contents/data-visualisations. 
Australian Medical Association (AMA) 2012. More Than Just a Union: A history of the $A M A$. Sydney: AMA. Available from: ama.com.au/article/more-justunion-history-ama.

Biggs, A. 2004. Medicare. Background Brief, 29 October. Canberra: Parliament of Australia. Available from: www.aph.gov.au/About_Parliament/Parliamentary _Departments/Parliamentary_Library/Publications_Archive/archive/ medicare.

Blewett, N. 1983. Second reading speech, House of Representatives. Hansard, 6 September. Canberra: Parliament of Australia.

Boxall, A. 2008. Resolving tensions: The development of Australia's health insurance system. PhD thesis, University of Sydney, Sydney.

Boxall, A., and Gillespie J. A. 2013. 'Making Medicare: The politics of universal health care in Australia. Sydney: NewSouth Publishing.

Cook, S. 1984. 'Doctors in all states but NSW halt strike.' The Australian, 7 April.

De Voe, J. 2003. 'A policy transformed by politics: The case of the 1973 Australian Community Health Program.' Journal of Health Politics, Policy and Law 28(1): 77-108. doi.org/10.1215/03616878-28-1-77.

Department of Health 2017. Annual Medicare Statistics. Canberra: Department of Health. Available from: www.health.gov.au/internet/main/publishing.nsf/ content/annual-medicare-statistics.

Department of the Treasury 2014. Budget 2014-15: Health. Canberra: Commonwealth of Australia. Available from: www.budget.gov.au/2014-15/ content/glossy/health/download/Health.pdf.

Duckett, S. 2014. 'Happy birthday, Medicare. Now, how can we make you better?' The Australian, 31 January.

Elliott, A. 2006. 'The best friend Medicare ever had? Policy narratives and changes in Coalition health policy.' Health Sociology Review 15(2): 132-43. doi.org/10.5172/hesr.2006.15.2.132.

Essential Research 2016. Essential Report: Privatising Medicare. [Online]. 28 June. Available from: essentialvision.com.au/?s=medicare\&searchbutton=Search.

Fraser, M. 1976. Transcript of interview with George Negus. This Day Tonight, 28 May.

Gillard, J. 2010. National Press Club Address, 26 May. Canberra. 
Glance, D. 2016a. 'Modernising Medicare is a great idea but needs a radical approach.' The Conversation, [Online], 11 February. Available from: theconversation.com/modernising-medicare-is-a-great-idea-but-needs-aradical-approach-54477.

Glance, D. 2016b. 'Simple processing and clever apps? Don't hold your breath for a user-friendly Medicare IT system.' The Conversation [Online], 21 June. Available from: theconversation.com/simple-processing-and-clever-apps-donthold-your-breath-for-a-user-friendly-medicare-it-system-61368.

Grant, R. 2000. Parties, press and polls: Institutional influences on public attitudes to social security and health policy in Australia, 1945-99. $\mathrm{PhD}$ thesis, The Australian National University, Canberra.

Haley, K. 1984. 'Concessions to the AMA achieve a fragile truce.' The Age, [Melbourne], 17 February.

Hawke, R. 1984. Speech by Prime Minister to Health and Research Employees' Association. [Transcript]. Sydney, 5 March. Available from: pmtranscripts. pmc.gov.au/release/transcript-6332.

Howard, J. 1995. Headland speech 1: The role of government-A modern Liberal approach. Menzies Research Centre 1995 National Lecture Series, Liberal Party of Australia.

Hunt, G. 2018. 'Highest bulk-billing rate on record.' Media release, 6 March. Canberra: Commonwealth of Australia.

Kelly, P. 1992. The End of Certainty: The story of the 1980s. Sydney: Allen \& Unwin.

Kelty, B. and Howe, B. 2003. 'The accord, industrial relations and the trade union movement.' In S. Ryan and T. Bramston (eds), The Hawke Government: A critical retrospective. Melbourne: Pluto Press.

Legge, K. and Metherell, M. 1984. 'The AMA drops call for 7pc rise.' The Age, [Melbourne], 5 January.

Lozano, R., Naghavi, M., Foreman, K., Lim, S., Shibuya, K., Aboyans, V., Abraham, J., et al. 2012. 'Global and regional mortality from 235 causes of death for 20 age groups in 1990 and 2010: A systematic analysis for the Global Burden of Disease Study 2010.' The Lancet 380(9859): 2095-128. doi.org/10.1016/S0140-6736(12)61728-0.

Milliner, K. 1984a. 'AMA refusing to see Blewett for talks.' The Canberra Times, 23 March. 
Milliner, K. 1984b. 'Talks between Dr Blewett and AMA try to find solution.' The Canberra Times, 3 April.

Muller, D. 2017. Double, double toil and trouble: The 2016 federal election. Research Paper Series 2016-17, 30 June. Canberra: Parliament of Australia.

Norman, R. and Gillespie, J. 2013. 'FactCheck: Were just 67\% of GP visits bulkbilled when Tony Abbott was health minister?' The Conversation, [Online], 4 September. Available from: theconversation.com/factcheck-were-just-67of-gp-visits-bulk-billed-when-tony-abbott-was-health-minister-17652.

O'Connor, G. 2003. Second reading speech, House of Representatives. Hansard, 16 June. Canberra: Parliament of Australia.

Organisation for Economic Co-operation and Development (OECD) 2015. Reviews of Health Care Quality: Australia 2015-Raising standards. Paris: OECD Publishing. Available from: read.oecd-ilibrary.org/social-issuesmigration-health/oecd-reviews-of-health-care-quality-australia-2015_97892 64233836-en\#page20. doi.org/10.1787/9789264233836-en.

Sammut, J. 2016. Medi-value: Health insurance and service innovation in Australia-Implications for the future of Medicare. Research Report No. 14, April. Sydney: Centre for Independent Studies. Available from: www.cis.org. $\mathrm{au} /$ publications/research-reports/medi-value-health-insurance-and-serviceinnovation-in-australia-implications-for-the-future-of-medicare/.

Sax, S. 1984. A Strife of Interests: Politics and policies in Australian health services. Sydney: Allen \& Unwin.

Scotton, R. B. and Macdonald, C. R. 1993. The Making of Medibank. Australian Studies in Health Service Administration No. 76. Sydney: School of Health Services Management, University of New South Wales.

Senate Community Affairs References Committee 2017. Value and Affordability of Private Health Insurance and Out-of-Pocket Medical Costs. Canberra: Parliament of Australia. Available from: www.aph.gov.au/Parliamentary_ Business/Committees/Senate/Community_Affairs/Privatehealthinsurance.

Shorten, B. 2016. 'Bill Shorten's budget reply in full.' Sydney Morning Herald, 5 May.

Wade, M. 2014. 'Medicare ahead by a mile in popularity stakes.' Sydney Morning Herald, 10 May. 
This text is taken from Successful Public Policy: Lessons from Australia and New Zealand, edited by Joannah Luetjens, Michael Mintrom and Paul 't Hart, published 2019 by ANU Press, The Australian National University, Canberra, Australia.

doi.org/10.22459/SPP.2019.11 